\title{
The Research on Smart Power Community Construction Mode
}

\author{
Shuzhe Li ${ }^{\text {a }}$, Lei Zhang ${ }^{\mathrm{b}}$, Xin Zhang, Dongqiang Heng \\ State Grid Henan Electric Power Company Luoyang Power Supply Company, Luoyang 471900, \\ China \\ a296457845@qq.com, b1015903240@qq.com
}

Keywords: Smart, intelligent, community.

\begin{abstract}
The intelligent power community as an important part of smart grid electricity sectors, to achieve real-time interaction between the grid and the user response, enhance grid integrated service capabilities to meet the needs of an important means of interactive marketing. Intelligent power cell and focuses on the smart power technology advanced, cost-effective, flexible interaction and other features. Papers discussing smart grids, intelligent power cell, based on the intelligent power residential construction were studied.
\end{abstract}

\section{Introduction}

Under the dual pressures of environmental issues and energy issues, human society is looking for a low consumption, low pollution, and low-emission economic growth. In this context, in order to ensure the sustainable development of China's energy strategy, to meet the electricity needs of rapid economic development, promote energy conservation, improve service levels, changes in grid development, the development of the smart grid has important strategic significance and reality It needs. With the introduction of smart grids, the concept of low-carbon economy and electric power system reform deepening, the traditional residential model is facing enormous challenges; the construction of smart power cell marked the official start of smart grid construction, the transformation of energy use, and the development of low-carbon green economic significance. Smart power, as an important part of the smart grid, and people's lives and profound impact on people's energy usage, so that people from the extensive mode of electricity into the electricity-intensive way into harmony electricity the new era.

\section{The Principles of Intelligent Residential Construction Projects}

Intelligent power cell construction, give full consideration to pilot smart power cell technology, prospective exploration, the window display needs, identify pilot projects focus on building direction: residential distribution automation, smart power interactive platforms, electric vehicle charging order, triple play, the power of information collection technology; reasonable integration of functional modules, to meet the information security requirements; the establishment of intelligent power cell showcase platform.

Intelligent residential construction project based on the following principles:

(1) practicality: Design and construction of smart power cell to the actual needs of residential customers in smart power as the fundamental starting point, residential customers have actually participated in the trial, to obtain meaningful data;

(2) Advanced: using a combination of advanced smart power, information and communication technology advanced concepts;

(3) Prospective: Consider development needs and various business development needs of the smart grid smart grid customer service.

(4) Demonstration: intelligent power cell should be fully considered demonstration value, formed in the State Grid Corporation system and for the government; society demonstration pilot application has the effect of various levels; 


\section{Program of Intelligent Community Building Projects}

Intelligent power residential construction overall solution integrates information collection, low-voltage distribution automation, electric vehicle charging pile management, community service interactive platform for intelligent power, residential smart home, residential property management, photovoltaic power generation systems, through a communication network connection , intelligent power and two-way interactive features showcase the power companies and their customers.

\section{Information Collection.}

Intelligent Community information collection on the customer realize the power of information, distributed power generation capacity information, charging pile consumption information desk area with tables and display information collection, including day point data, using graphs, histograms, pie charts and other visual mode display. While achieving providing voltage and current signals to distribution automation system, which for the first time in the country to achieve a precise positioning and low voltage faults. And other information collection system is only the realization of customer electricity information collection functions.

Electricity customers file information required by this acquisition system is responsible for the company's existing systems; the second is the power of the system is responsible for collecting information and data collection are swapped to the system, the system completes the appropriate marketing business application; third of the collection system responsible for the collection of electricity information data curve data exchanged primarily to the completion of an interactive website and interactive website customers intelligent interactive terminals through Property Management system Master-way information exchange

\section{Distribution Automation Cell.}

General Distribution Automation Distribution Automation System Intelligent Community to achieve the collection and fault location of power distribution equipment data; intelligent community distribution automation to achieve not only to achieve the collection and fault location of power distribution equipment data, and to achieve a contra lateral equipment acquisition, and information collection through the data provided, to achieve precise positioning and low voltage faults.

Through distribution terminals, high-power distribution room, current low voltage on the line, three-phase voltage, active power, reactive power, frequency, power factor and other line parameters (remote measurement acquisition). The access, the user Zero Line low voltage alarm and protection of distribution terminal device remote signaling information collected by the distribution network sub-station and the master server forwards the information automatic fault detection and isolation: cell distribution automation distribution system automatic fault diagnosis, automatic isolation (need to be set up after the master distribution network in order to further improve) to reduce the scope of power failure to restore power supply to achieve the non-faulted segment of video surveillance: the important area of the cell installed in the distribution chamber (stations) and other video surveillance equipment, and the image is transmitted to the monitoring information and distribution network operation and maintenance center. system combines data online interactive business information collection, and by analyzing the information collection and distribution automation upload data to achieve a low failure Exact positioning of distribution terminals Ethernet communication through a variety of ways, fiber optic communications set will preclude the information transmitted to the station with electronic, with electronic station can receive and send messages multiple distribution terminals and control commands, and with Distribution master communication, information distribution can be achieved on the master forwarding and command forwarding.

\section{Smart Electricity Service Interactive Platform.}

Intelligent Community intelligent power service interactive platform with traditional electricity service interactive platform (system) comparison, the Intelligent Community intelligent power service interactive platform to achieve the intelligent community information display business, intelligence community customer's interactive services, intelligent home appliances management business. 
Smart electricity service interactive platform accepted by the network intermediate library and the Internet database information from electricity services and community interaction, implementation and cell distribution automation system, charging pile management systems, information collection system, property management system connections. Combined with the practical requirements of the municipal electric power company, to achieve the following features and interfaces: User Management: complete system users, increase the system administrator, modify, delete. Distribution automation query: extended online community via intelligent power systems, low-voltage distribution automation system equipment information and running status display and associated information centralized analytic queries. Online charging pile business: charging point information display, customer charging information query, charge pile appointment charging applications, etc., can also query the current usage and charging pile location. Power information dissemination: the power of information to customers, distributed power generation capacity information, charging pile consumption information desk area with tables show information, including daily point data, preclude the use of graphs, bar charts, pie charts, etc. visually display.

\section{Smart Home.}

Intelligent Community of intelligent building automation comparison with home, intelligent home intelligent community focused intelligent household appliances control through intelligent interactive terminals, intelligent home appliances outlet to achieve information collection, monitoring, analysis and control, home appliances linkage. The building automation focuses on achieving elevator, central air conditioning and other control and coordination. Smart Home Services online customers can achieve electrical household appliances, equipment information, display real-time power consumption information for our customers to provide electricity reference policy, customers through an interactive website, can smart appliances, smart socket installation ordinary household appliances, as well as the implementation of security equipment remote control.

\section{Intelligent Community Project Proposal}

Intelligent power, intelligent power distribution and other services fully reflects the smart grid applications in a cell in the city, such as information collection, electric vehicle charging, power distribution automation, interactive smart electricity services, these businesses belong to the electricity business, higher maturity of its technical and operational aspects of equipment operation and management infrastructure is better, there is a good prospect, it could be extended. Smart home, intelligent property, and other services as it involves real estate developers, users, equipment producers, system design, and many other parties, technical standards need to be unified, business model need to determine technology needs further improvement, a significant reduction in the scale of investment required, can be Construction of the pilot experience gained over the situation and actively and steadily push forward, it is recommended that:

Further promote the intelligence community. Intelligent power, intelligent power distribution and other services fully reflects the smart grid technology in urban cell, the higher the maturity of its technical and operational aspects of equipment operation and management infrastructure is better, there is a good prospect, worthy of promotion Application;

Intelligent power cell further strengthen relevant national regulations, norms develop. Intelligent Community embodies the future home of the concept and model, has a very strong prospects and business value. But now, some of considerable practices are not introduced, such as electric vehicles interface specification, smart appliances interface specification, so that the production of different interfaces on the market more products, but incompatible, thus further strengthening the intelligent power cell-related national regulations, norms The formulation is very necessary.

\section{Summary}

Since intelligent power cell commissioning, equipment running well, we get a lot of real data and operational experience, residential construction and commissioning to achieve the expected goal, to create a safe, comfortable, convenient, energy saving, environmental protection, intelligence, 
sustainable development modern living demonstration area, fully embodies the "technologically advanced, energy efficient, safe, reliable, flexible and interactive, friendly and Ji put" feature, showing future lifestyle. Meanwhile, the smart power residential construction is a rich connotation, involving a wide range, reflecting the large number of research results in the field of comprehensive smart grid project, not only for achieving sustainable, efficient, clean, reliable power is important, but also to the community widespread smart grid construction concept, has played a positive role model.

\section{Reference}

[1] Xie Kai, Liu Yongqi, Zhu Zhizhong, China for the future smart grid electricity, 2008, 41 (6): 19-22

[2] Luyuan Rong, China power grid construction Beijing: China Electric Power Press, 2009

[3] Yang Qiyu,Liu Bin, Yu Jing Hu. Smart grid technology Hunan University, 2010, (23) 4: 100-105

[4] Niu Huicheng, Hao Zhong, Zhang Yan. Summary of reliability and economy of smart grid expansion planning, Power System and Automation.2010, 21 (1): 25-27

[5] Wang Xinmin. Market economy and new methods of power planning, China's power, 2009,32 (9): 8-10

[6] Wang Chengshan,Wang Sai. Discussion on Power Systems under, a market condition power system planning work, 2005, 29 (9): 82-86 